\title{
Landscape of tobacco control in sub-Saharan Africa
}

\author{
Catherine 0 Egbe 10 , ${ }^{1,2}$ Peter Magati, ${ }^{3,4}$ Emma Wanyonyi, ${ }^{4}$ Leonce Sessou, ${ }^{5}$ \\ Ellis Owusu-Dabo, ${ }^{6}$ Olalekan A Ayo-Yusuf (1) 7,8
}

${ }^{1}$ Alcohol, Tobacco and Other Drug Research Unit, South African Medical Research Council, Pretoria, Gauteng, South Africa

${ }^{2}$ Department of Public Health, Sefako Makgatho Health Sciences University, Pretoria, Gauteng, South Africa

${ }^{3}$ School of Economics, University

of Nairobi, Nairobi, Kenya

${ }^{4}$ International Institute for Legislative Affairs, Nairobi, Kenya

${ }^{5}$ African Tobacco Control Alliance, Lome, Togo

${ }^{6}$ Department of Global Health, School of Public Health, Kwame Nkrumah University of Science and Technology, Kumasi, Ashanti, Ghana

${ }^{7}$ Africa Center for Tobacco Industry Monitoring and Policy Research, Sefako Makgatho Health Sciences University, Medunsa, Pretoria, Gauteng, South Africa

${ }^{8}$ School of Health Systems and Public Health, University of Pretoria, Pretoria, Gauteng, South Africa

Correspondence to

Dr Catherine 0 Egbe, Alcohol, Tobacco and Other Drug Research Unit, South African Medical Research Council, Pretoria 0001, Gauteng, South Africa;

Catherine.Egbe@mrc.ac.za

Received 1 June 2021

Accepted 3 November 2021

Check for updates

(C) Author(s) (or their employer(s)) 2022. No commercial re-use. See rights and permissions. Published by BMJ.

To cite: Egbe $\mathrm{CO}$, Magati $\mathrm{P}$,

Wanyonyi $\mathrm{E}$, et al.

Tob Control

2022:31:153-159.

\section{ABSTRACT}

Yearly, tobacco use kills about 8 million people globally, $80 \%$ of whom live in low/middle-income countries. Given sub-Saharan Africa's (SSA) rapidly increasing and youthful population, growing incomes and the increased presence of the tobacco industry, the number of tobacco users is growing. The region is predicted to face a heavier burden of tobacco-related diseases and deaths in the future. We examined the policy, advocacy, economic and media landscapes of tobacco control as well as tobacco industry interference in SSA. We also highlighted key challenges and priorities for intervention in the region. Their vast financial power has enabled transnational tobacco companies to interfere in tobacco control and slow down policy implementation efforts in SSA. Despite recent gains, inadequate investment in tobacco control has prevented effective tobacco control implementation in SSA. Other challenges include limited locally generated evidence and limited support from mainstream media to back policy and advocacy efforts. Finally, taxation, which is one of the most effective tools for tobacco control, is not yet adequately used in SSA partly due to nonharmonised taxation rates as well as exaggerated and false claims about the potential impacts of increasing taxes, especially that it will increase smuggling. Key priorities to address these challenges include continued strategic funding, capacity building of government and advocacy personnel to strengthen tobacco control governance, regional and institutional cooperation, harmonisation of subregional tax policies, cooperation among international funders, and increased industry monitoring and research in SSA.

\section{INTRODUCTION}

Of 8 million tobacco-related deaths annually, $80 \%$ occur in low/middle-income countries (LMICs). ${ }^{1}$ Sub-Saharan Africa (SSA) has the lowest tobacco use prevalence ${ }^{1}$ and the youngest population, but the region has witnessed the largest relative increase in the number of tobacco users than in other regions, ${ }^{12}$ making it the predicted future tobacco epidemic epicentre. ${ }^{1}$

This paper explores the tobacco control (TC) policy/advocacy, media and economic landscape in SSA, as well as key challenges and priorities.

\section{TOBACCO EPIDEMIC IN SSA}

Smoking prevalence in the WHO AFRO region remains the lowest among all WHO regions, ${ }^{3}$ but the region is predicted to experience the second lowest real decrease in smoking prevalence of $3.2 \%$ due to smaller decline in prevalence. ${ }^{3}$ The number of tobacco smokers in the AFRO region was estimated at 52 million in 2000 but increased to 66 million in 2015 and is projected to increase to 84 million in
2025 (there will be a $61.5 \%$ relative increase in the number of smokers compared with 2000) making the region one of the only two regions in the world projected to have an increase in the number of tobacco smokers, the second being the Eastern Mediterranean region. ${ }^{3}$ SSA remains a viable investment destination for the tobacco industry because of the region's youthful population (the population is predicted to double by 2050). ${ }^{45}$ Markets in SSA are often unregulated, cigarette prices are low, and TC laws are weak or when strong, not fully implemented and enforced. ${ }^{6}$ Limited resources are allocated to healthcare; health infrastructure is poor, ${ }^{7}$ industry interference is rife, ${ }^{8}$ effective national TC governance and political goodwill to implement tobacco legislation is sometimes lacking ${ }^{9}$ creating a possibility of more devastating health effects if the predicted tobacco epidemic occurs in the region.

\section{SSA'S TC POLICY AND ADVOCACY LANDSCAPE}

In SSA, 43 of 46 countries have signed, ratified or acceded to the WHO Framework Convention on Tobacco Control (WHO FCTC) ${ }^{10}$ (table 1), representing about $25 \%$ of all parties to the treaty. However, ratifying or acceding to the FCTC is only the first step towards effective TC. Countries must domesticate the treaty by formulating and implementing comprehensive and effective TC policies to benefit fully.

Figure 1 shows percentage of SSA countries with laws covering three key FCTC articles: 100\% smoke-free policy (Article 8), health warning labels (Article 11), bans on tobacco advertisement, promotion and sponsorships (Article 13) ${ }^{11}$ Overall, a higher percentage of SSA countries appears to be doing well in banning tobacco advertisement, promotion and sponsorship, followed by health warnings on tobacco packages. However, for all provisions of a $100 \%$ smoke-free policy, less than $50 \%$ of SSA countries have put in place appropriate legislation. ${ }^{11}$

FCTC implementation requires effective TC governance involving a whole of government approach and intergovernmental cooperation as well as multisectoral implementation of TC. ${ }^{12}$ Many countries in SSA now recognise the role of civil society organisations (CSOs) as legitimate representation of the people, for example, in Nigeria, CSOs are members of the National Tobacco Control Committee set up to see to the effective implementation of TC. ${ }^{13}$ However, dynamics of TC policymaking are complexgovernment ministries, especially commerce/ trade, finance and agriculture, sometimes work in opposition to health ministries. ${ }^{14}$ The industry enlists government officials in opposing FCTC 
Table 1 WHO FCTC and protocol to eliminate illicit trade in tobacco products status with retail price and total tax share of the most sold brand of cigarettes, in sub-Saharan Africa

\begin{tabular}{|c|c|c|c|c|c|c|c|c|c|c|}
\hline \multirow[b]{2}{*}{ Country } & \multicolumn{2}{|l|}{ FCTC status } & \multicolumn{2}{|l|}{ PEITTP status } & \multirow{2}{*}{$\begin{array}{l}\text { Retail } \\
\text { price in } \\
\text { US\$ }\end{array}$} & \multirow[b]{2}{*}{ Excise tax } & \multirow{2}{*}{$\begin{array}{l}\text { VAT/sales } \\
\text { tax }\end{array}$} & \multirow{2}{*}{$\begin{array}{l}\text { Import } \\
\text { duties }\end{array}$} & \multirow{2}{*}{$\begin{array}{l}\text { Other } \\
\text { taxes }\end{array}$} & \multirow{2}{*}{$\begin{array}{l}\text { Percentage of } \\
\text { total tax }\end{array}$} \\
\hline & Signature & Ratification* & Signature & Ratification* $\dagger$ & & & & & & \\
\hline Angola & 29 Jun 2004 & 20 Sep 2007 & - & - & 2.34 & $16.43 \%$ & $15.38 \%$ & $0.00 \%$ & $3.67 \%$ & 35.47 \\
\hline Benin & 18 Jun 2004 & 3 Nov 2005 & $24 \operatorname{Sep} 2013$ & 6 Jul 2018 & 1.56 & $3.93 \%$ & $2.17 \%$ & $5.82 \%$ & $0.19 \%$ & 12.11 \\
\hline Botswana & 16 Jun 2003 & 31 Jan 2005 & 1 Oct 2013 & - & 0.90 & $7.77 \%$ & $1.40 \%$ & $0.00 \%$ & $0.37 \%$ & 9.54 \\
\hline Burkina Faso & 22 Dec 2003 & 31 Jul 2006 & 8 Mar 2013 & 30 Mar 2016 & 4.31 & $35.15 \%$ & $10.71 \%$ & $0.00 \%$ & $6.30 \%$ & 52.17 \\
\hline Burundi & 16 Jun 2003 & 22 Nov 2005 & - & - & 1.35 & $28.25 \%$ & $15.25 \%$ & $0.00 \%$ & $0.00 \%$ & 43.50 \\
\hline Cabo Verde & 17 Feb 2004 & 4 Oct 2005 & - & 16 Oct $2019^{*}$ & 1.04 & $22.00 \%$ & $15.25 \%$ & $0.00 \%$ & $0.00 \%$ & 37.25 \\
\hline Cameroon & 13 May 2004 & 3 Feb 2006 & - & - & 2.66 & $12.92 \%$ & $2.78 \%$ & $3.73 \%$ & $0.05 \%$ & 19.49 \\
\hline $\begin{array}{l}\text { Central African } \\
\text { Republic }\end{array}$ & 29 Dec 2003 & 7 Nov 2005 & - & - & 1.26 & $20.51 \%$ & $16.14 \%$ & $4.79 \%$ & $1.75 \%$ & 43.19 \\
\hline Chad & 22 Jun 2004 & 30 Jan 2006 & - & 13 Jun $2018^{*}$ & - & & - & - & - & - \\
\hline Comoros & 27 Feb 2004 & $24 \operatorname{Jan} 2006$ & - & 14 Oct $2016^{*}$ & 0.90 & $32.10 \%$ & $15.25 \%$ & $0.00 \%$ & $4.24 \%$ & 51.60 \\
\hline Congo & 23 Mar 2004 & 6 Feb 2007 & - & 14 May 2015 & 0.96 & $62.76 \%$ & $9.09 \%$ & $0.00 \%$ & $1.99 \%$ & 73.84 \\
\hline Côte d'Ivoire & 24 Jul 2003 & 13 Aug 2010 & 24 Sep 2013 & 25 May 2016 & 1.35 & $10.97 \%$ & $15.90 \%$ & $0.00 \%$ & $0.00 \%$ & 26.87 \\
\hline $\begin{array}{l}\text { Democratic } \\
\text { Republic of Congo }\end{array}$ & 28 Jun 2004 & 28 Oct 2005 & 9 Dec 2013 & - & 1.26 & $16.29 \%$ & $15.25 \%$ & $0.00 \%$ & $3.00 \%$ & 34.54 \\
\hline Equatorial Guinea & - & 17 Sep 2005* & - & - & 0.51 & $38.31 \%$ & $13.79 \%$ & $0.00 \%$ & $0.00 \%$ & 52.11 \\
\hline Eritrea & - & - & - & - & 0.90 & $8.02 \%$ & $6.25 \%$ & $9.62 \%$ & $0.32 \%$ & 24.21 \\
\hline Eswatini & 29 Jun 2004 & 13 Jan 2006 & - & 21 Sep 2016* & - & $\ldots$ & - & - & - & - \\
\hline Ethiopia & 25 Feb 2004 & 25 Mar 2014 & - & - & 1.15 & $40.78 \%$ & $10.39 \%$ & $0.00 \%$ & $0.00 \%$ & 51.16 \\
\hline Gabon & 22 Aug 2003 & 20 Feb 2009 & 10 Jan 2013 & 1 Oct $2014 \dagger$ & 1.81 & $8.44 \%$ & $4.94 \%$ & $7.79 \%$ & $0.38 \%$ & 21.55 \\
\hline Gambia & 16 Jun 2003 & 18 Sep 2007 & - & $26 \operatorname{Sep} 2016^{*}$ & 1.35 & $35.71 \%$ & $6.92 \%$ & $1.74 \%$ & $4.38 \%$ & 48.75 \\
\hline Ghana & 20 Jun 2003 & 29 Nov 2004 & 24 Sep 2013 & - & 0.88 & $16.51 \%$ & $14.89 \%$ & $0.00 \%$ & $0.35 \%$ & 31.75 \\
\hline Guinea & 1 Apr 2004 & 7 Nov 2007 & - & 9 May $2017^{*}$ & 0.52 & $3.89 \%$ & $2.87 \%$ & $2.60 \%$ & $0.36 \%$ & 9.71 \\
\hline Guinea-Bissau & - & 7 Nov $2008^{*}$ & 24 Sep 2013 & & - & & - & - & - & - \\
\hline Kenya & 25 Jun 2004 & 25 Jun 2004 & 29 May 2013 & 4 May 2020 & 2.32 & $25.26 \%$ & $13.79 \%$ & $0.00 \%$ & $0.00 \%$ & 39.05 \\
\hline Lesotho & 23 Jun 2004 & $14 \operatorname{Jan} 2005$ & - & - & 2.77 & $37.54 \%$ & $13.04 \%$ & $0.00 \%$ & $0.00 \%$ & 50.58 \\
\hline Liberia & 25 Jun 2004 & 15 Sep 2009 & - & - & 1.41 & $46.52 \%$ & $9.09 \%$ & $1.07 \%$ & $0.11 \%$ & 56.78 \\
\hline Madagascar & 24 Sep 2003 & 22 Sep 2004 & 25 Sep 2013 & 21 Sep 2017 & 1.05 & $63.61 \%$ & $16.67 \%$ & $0.00 \%$ & $0.15 \%$ & 80.43 \\
\hline Malawi & - & - & - & - & 0.71 & $42.16 \%$ & $14.16 \%$ & $0.00 \%$ & $0.00 \%$ & 56.32 \\
\hline Mali & 23 Sep 2003 & 19 oct 2005 & 8 Jan 2014 & 17 Jun 2016 & 1.44 & $11.18 \%$ & $9.19 \%$ & $6.51 \%$ & $0.81 \%$ & 27.69 \\
\hline Mauritania & 24 Jun 2004 & 28 Oct 2005 & & & 1.07 & $1.99 \%$ & $1.66 \%$ & $1.37 \%$ & $0.89 \%$ & 5.91 \\
\hline Mauritius & 17 Jun 2003 & 17 May 2004 & - & 26 Jun $2018^{*}$ & 3.75 & $68.15 \%$ & $13.04 \%$ & $0.00 \%$ & $0.00 \%$ & 81.19 \\
\hline Mozambique & 18 Jun 2003 & 14 Jul 2017 & - & - & 0.85 & $14.00 \%$ & $14.53 \%$ & $0.00 \%$ & $0.00 \%$ & 28.53 \\
\hline Namibia & $29 \operatorname{Jan} 2004$ & 7 Nov 2005 & - & - & 3.58 & $29.00 \%$ & $13.04 \%$ & $0.00 \%$ & $0.00 \%$ & 42.04 \\
\hline Niger & 28 Jun 2004 & 25 Aug 2005 & - & 12 Jul 2017* & 0.90 & $14.96 \%$ & $15.97 \%$ & $0.00 \%$ & $0.89 \%$ & 31.82 \\
\hline Nigeria & 28 Jun 2004 & 20 Oct 2005 & - & 8 Mar 2019* & 1.05 & $30.00 \%$ & $6.98 \%$ & $0.00 \%$ & $0.00 \%$ & 36.98 \\
\hline Rwanda & 2 Jun 2004 & 19 oct 2005 & - & - & 1.06 & $49.00 \%$ & $15.25 \%$ & $0.00 \%$ & $0.00 \%$ & 64.25 \\
\hline $\begin{array}{l}\text { Sao Tome \& } \\
\text { Principe }\end{array}$ & 18 Jun 2004 & 12 Apr 2006 & - & - & 1.42 & $29.15 \%$ & $0.00 \%$ & $4.54 \%$ & $0.00 \%$ & 33.69 \\
\hline Senegal & 19 Jun 2003 & 27 Jan 2005 & - & 31 Aug 2016* & 1.26 & $22.99 \%$ & $15.25 \%$ & $0.00 \%$ & $0.00 \%$ & 38.24 \\
\hline Seychelles & 11 Sep 2003 & 12 Nov 2003 & - & $7 \operatorname{Jan} 2020^{*}$ & 7.12 & $56.46 \%$ & $13.04 \%$ & $0.00 \%$ & $0.00 \%$ & 69.51 \\
\hline Sierra Leone & - & 22 May 2009* & - & - & 0.62 & $4.29 \%$ & $13.04 \%$ & $5.01 \%$ & $0.21 \%$ & 22.56 \\
\hline South Africa & 16 Jun 2003 & 19 Apr 2005 & 10 Jan 2013 & - & 2.62 & $39.69 \%$ & $13.04 \%$ & $0.00 \%$ & $0.00 \%$ & 52.73 \\
\hline South Sudan & - & - & - & - & 2.44 & $33.90 \%$ & $15.25 \%$ & $0.00 \%$ & $16.95 \%$ & 66.10 \\
\hline Togo & 12 May 2004 & 15 Nov 2005 & 9 Jan 2014 & $31 \operatorname{Jan} 2018$ & 2.57 & $40.47 \%$ & $13.04 \%$ & $0.00 \%$ & $0.00 \%$ & 53.51 \\
\hline Uganda & 5 Mar 2004 & 20 Jun 2007 & & & 1.26 & $25.46 \%$ & $15.25 \%$ & $0.00 \%$ & $0.65 \%$ & 41.37 \\
\hline $\begin{array}{l}\text { United Republic of } \\
\text { Tanzania }\end{array}$ & $27 \operatorname{Jan} 2004$ & 30 Apr 2007 & 24 Sep 2013 & - & 1.09 & $27.50 \%$ & $7.08 \%$ & $0.00 \%$ & $0.00 \%$ & 34.58 \\
\hline Zambia & - & 23 May $2008^{*}$ & - & - & 1.74 & $14.71 \%$ & $15.25 \%$ & $0.00 \%$ & $0.00 \%$ & 29.97 \\
\hline Zimbabwe & - & 4 Dec $2014^{*}$ & - & - & 1.16 & $25.00 \%$ & $13.79 \%$ & $0.00 \%$ & $0.00 \%$ & 38.79 \\
\hline
\end{tabular}

Data source for FCTC and PEITTP status: United Nations Treaties. ${ }^{1066}$ Price and tax share data source: 2021 WHO Global Tobacco Control Report. ${ }^{39}$

Values in bod are the ones which are above the threshold of $75 \%$ as required by the WHO FCTC.

${ }^{*}$ Accession.

†Acceptance.

FCTC, Framework Convention on Tobacco Control; PEITTP, Protocol to Eliminate Illicit Trade in Tobacco Products. 


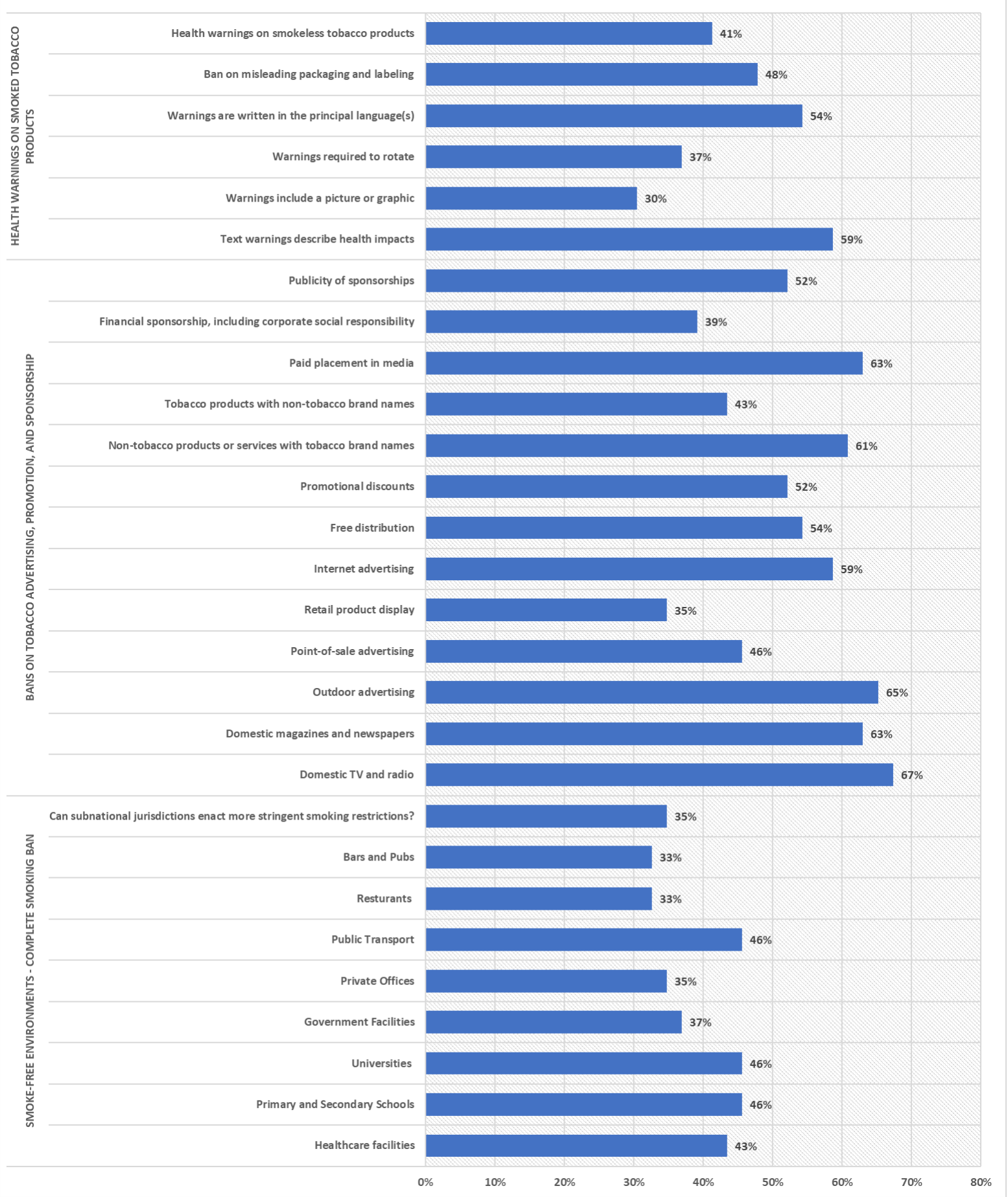

Figure 1 Percentage of SSA countries with comprehensive tobacco policies in three key areas (data source: Campaign for Tobacco Free Kids Policy Factsheets). Reference: Campaign for Tobacco Free Kids. Tobacco Control Laws: Policy Factsheets. 2021; https://wwwtobaccocontrollawsorg/legislation/ factsheet/. Accessed 20 April 2021. SSA, sub-Saharan Africa.

provision and implementation in many SSA countries. In Nigeria, some policymakers were enlisted to stall legislative procedure on the National Tobacco Control Act 2015. ${ }^{15}$ In South Africa, some officials of the 'Hawks' (special anticorruption unit within the police service), the South African Police Service, the South African Revenue Services and other government parastatals were implicated in a case of 'advancing the interest of commercial enterprises' including the tobacco industry. ${ }^{16}$ In some East African countries, policymakers were reported to have collected bribes to advance the position of the tobacco industry both at country and international levels. ${ }^{17}$

Lack of capacity also challenges policy formulation and implementation. Most SSA health ministries have a TC focal point ${ }^{18}$ but these are not exclusively dedicated to TC activities. Health ministries may need more negotiation and diplomacy skills 
to bring together other government departments/agencies to discuss and agree on common TC approaches. ${ }^{19} 20$

A key barrier to effective policy implementation in most African countries is the limited government investment in TC. With limited health budgets in most SSA countries and falling behind the widely recommended 5\% of Gross Domestic Product earmarked for the health sector, ${ }^{21}$ or the allocation of $15 \%$ of budget for health financing pledged in the Abuja Declaration, ${ }^{722}$ it is not a surprise that most countries do not adequately fund TC. ${ }^{23}$ Very little is known of the amount of money spent by African governments on TC and of the seven countries with data, government spending on tobacco control amounts to US $\$ 337000$, or about US $\$ 0.006$ per capita, ${ }^{23}$ compared with US $\$ 4.08$ per capita for HIV/AIDs spending. ${ }^{24}$ Available data show that 11 SSA countries impose special levies or taxes on tobacco products but only six (Botswana, Cote d'Ivoire, Gabon, Kenya, Madagascar and Mauritius) use some of these funds for TC. ${ }^{25}$ The lack of government funding creates a gap which to some extent has been filled by international funders coordinated by the WHO. ${ }^{23}$ Such funders include International Development Research Centre, The Union, Bloomberg initiatives through the Campaign for Tobacco Free Kids, and the Bill and Melinda Gates Foundation. ${ }^{23}$ CSOs and non-governmental organisations ${ }^{15} 26$ have been vocal and visible in the SSA political space, contributing to awareness creation and the advancement of the adoption of TC legislation in the region. ${ }^{27}$ However, many CSOs involved in advocacy are relatively young, lacking experience and sustainable means beyond donor funding. ${ }^{28}$ Governments must invest in national TC programmes, with donor agencies supporting advocacy to complement government's initiatives. For example, Gates Foundation (through the Centre for Tobacco Control in Africa) provides support to some African countries (including government and other stakeholders). ${ }^{2930}$

Limited locally generated data underpin TC efforts in SSA, ${ }^{31}$ given insufficient national and international research funding to inform TC policy and advocacy. Mamudu and colleagues investigating tobacco-related published research in SSA over 50 years found that over half of the publications were from South Africa and Nigeria. ${ }^{31}$ International funding of TC in SSA is mostly channelled into policy engagement and advocacy, with less support for local research except for a few cases like the more recent funding support through the African Capacity Building Foundation for industry monitoring capacity building by the Africa Centre for Tobacco Industry Monitoring and Policy Research at Sefako Makgatho Health Sciences University and Research Unit on the Economics of Excisable Products at University of Cape Town, both based in South Africa. Limited local funding allows international funders to set the TC research agenda in SSA, where there are few core TC researchers, compounded by a brain drain as researchers seek better opportunities outside the region. ${ }^{31}$

\section{ECONOMIC LANDSCAPE OF SSA TC}

The tobacco industry increasingly uses narratives on economic prosperity (mostly unvalidated) to slow TC progress in SSA. ${ }^{32-34}$ The industry routinely argues that increasing tobacco excise tax will reduce licit tobacco demand sharply, decreasing government tax revenue $e^{35}$ and expanding the illicit cigarette market. Empirical evidence, however, shows that raising taxes is the most effective way to reduce tobacco use and results in higher tax revenue, ${ }^{36}{ }^{37}$ validating the FCTC's recommendation of a minimum $75 \%$ tax share of the retail price of tobacco. ${ }^{38}$ However, only Madagascar's and Mauritius' tax shares are above the recommended level (table 1).$^{39}$ Policymakers in some countries hesitate to raise taxes due to misinformation and industry interference, especially in economic, trade and finance ministries, for example, in Kenya. ${ }^{40}$ Also, SSA countries belong to multiple regional trading and customs blocks, so harmonisation of tobacco excise taxes in the region is essential to decrease incentives for cross-border bootlegging and illicit trade due to price differences between countries. ${ }^{41-43}$ Some countries are members of more than one trading and customs blocks, for example, the Economic Community of West African State and Members of the West African Economic and Monetary Union. These blocks which have some mutual members impose minimum tax policies that could be levied by member countries but these policies are often not uniform as seen in 2017 tobacco tax directives by these bodies. ${ }^{43}$

To improve tobacco tax collection and curb illicit trade, costeffective technology such as Kenya's track-and-trace system and significant financial penalties can be adopted. ${ }^{37}$ This is in addition to being party to the Protocol for the Elimination of Illicit Trade in Tobacco Products (20 SSA countries are already parties, table 1)..$^{10}$ The track-and-trace system helps determine whether a product was legally produced or imported into the country to confirm taxes have been paid. This is done through marking tobacco products with secure and unique markings (tax stamp) for tracking purposes. The impact of this system can be observed by the significant reduction of illicit trade from $15 \%$ of total consumption at the time of installation of the system in 2013 to $5 \%$ as of $2015 .{ }^{44}$ Another factor affecting TC in SSA is increased investment in leaf production, partly fuelled by lower production costs in SSA and stringent TC measures in high-income countries. ${ }^{45}$ Tobacco leaf export value exceeded 1\% of GDP in only four countries globally and three of these were countries in SSA (Malawi, 8.45\%; Zimbabwe, 3.43\% and Mozambique, $1.77 \%){ }^{45}$ Some governments (likely influenced by the tobacco industry) believe tobacco plays an important role in improving economic fortunes through employment creation and foreign earnings. ${ }^{32}{ }^{46}$ Empirical results from research on tobacco farming suggest that these economic prosperity narratives are exaggerated: fewer farmers grow tobacco than reported by industry proponents; the true cost of tobacco farming is very high. ${ }^{47}$ Most tobacco farmers are forced into contract farming, paying higher prices for inputs than other farmers in the same geographical locations, incurring higher labour costs for this labour-intensive crop, making little or no profit, ${ }^{4648} 49$ and exposing families, including children, to the health hazards associated with tobacco harvesting. ${ }^{47}$

\section{TC MEDIA LANDSCAPE IN SSA}

News media set the agenda in public health by framing and shaping public opinion, but TC has not benefited adequately from the media. ${ }^{50}$ There is competition to use the media to push for or against TC: the media in SSA are the future battlefield for TC and this has become quite prominent especially in South Africa where the industry has launched several media campaigns to protest against TC regulations, for example, \#handsoffmychoices against South Africa's tobacco control bill, \#Notjustjobs $^{51}$ and \#takebackthetax against tax increases under the guise of fighting illicit trade which they have been found to be part of $^{5253}$ and recently during the COVID-19 lockdown tobacco sales ban in South Africa on various social media platforms. ${ }^{54}$ News media in SSA often tacitly portray the industry positively, allowing subtle advertising while reporting on the industry's 
corporate social responsibility activities. ${ }^{1550}$ Media practitioners may be largely unaware of tobacco industry tactics due to how the industry ties their campaigns to issues that are of importance to a vast majority of the population like jobs and human rights. New media (social media and digital platforms) enable the industry to contravene country policies banning advertising, sponsorship and promotion: ${ }^{55} 56$ the industry recruits social media influencers to promote their products and entice young people (the main consumers of new media content). ${ }^{57}$ Acknowledging the potential of media to drive TC agenda, some TC organisations, for example, in Nigeria, ${ }^{15}$ deliberately build relationships and media capacity to engage in TC in a timely, analytical and factual manner. The advent of new media has enabled advocates and governments to create their own 'spaces' to advance TC messaging to the populations in a timely and costfriendly manner ${ }^{58}$ for example, the \#ProtectOurNext campaign in South Africa ${ }^{59}$ and Smoke Free Uganda project. ${ }^{60}$ However, traditional and new media need to be more strategically used as $\mathrm{TC}$ resources in SSA.

\section{Tobacco industry interference}

Industry interference remains one of the biggest challenges faced by TC in SSA. ${ }^{9}$ With the advantage of big capital to lobby governments officials ${ }^{1617}$ and pay social influencers, the industry's promotional and political activities may be the single most significant vector of the tobacco epidemic in the region. ${ }^{61}$ This situation is not peculiar to SSA, ${ }^{61}$ but weak TC governance and political will to make and implement comprehensive TC policies make this a bigger challenge in this region. The industry has become innovative in their strategies to expand the SSA market by introducing new tobacco and nicotine products to bypass current laws like the oral nicotine pouches introduced in some SSA countries like Kenya and Tanzania, ${ }^{62}{ }^{63}$ bribing government officials ${ }^{16} 17$ and leveraging on the COVID-19 pandemic to present themselves as positive contributors to society, ${ }^{8}$ making tobacco control advocates struggle to catch up with their tactics.

\section{KEY PRIORITIES FOR TC IN SSA}

Given the challenges of TC in SSA, we highlight some key priorities for the region.

1. Tobacco industry monitoring and countering: industry monitoring must be stepped up to proactively counter industry activities to undermine TC in the region. Awareness raising on the harms of tobacco and nicotine products should be combined with informing the public about the industry's role in promoting nicotine addiction and their attempt to divert attention from prevention to 'harm reduction' in a region still at an early stage of the tobacco epidemic. ${ }^{64}$

2. Regional and institutional cooperation: more cooperation between subregional bodies to harmonise subregional tax policies, and between government, research institutions and CSOs in the region would enhance knowledge sharing and transfer, judicious use of scarce resources and prevent duplication of efforts. This is in line with the harmonisation of policies, including taxes and strategies on issues such as education, investment treaties, etc both at the African Union and within the African Continental Free Trade agreement, and would help create a win-win scenario for all countries and the region. International funders should also consider requiring some level of regional cooperation and knowledge transfer as a key performance area in their grants to countries, institutions and CSOs. This would meet the recommen- dations of the WHO FCTC Articles 20 and 22 on international cooperation/collaboration.

3. Cooperation among international funders: international funders would use resources more effectively and efficiently with better cooperation rather than competition between organisations working in SSA. Some of the international funders work simultaneously in several of the same countries. While there is already some cooperation between international funders, more cooperation and better synergy among funders would ensure wider coverage of countries and better use of limited resources.

\section{LIMITATIONS}

SSA is comprised of countries which are different in tobacco use prevalence and advancement in TC. In this paper, we have attempted to paint a picture of TC in SSA. In doing this, we acknowledge that it is practically impossible to write a paper which would capture all the details of TC, including key data needs by country within the region. Also, despite the progress recorded in some countries in the region, research and publications to document these successes are lacking. While research needs for LMICs that are applicable for the implementation of the WHO FCTC in SSA can be found elsewhere, ${ }^{65}$ this paper gives a general description of the landscape of TC and makes recommendations which we believe are applicable, and would be beneficial to all countries if implemented irrespective of their progress in TC over the years.

\section{CONCLUSION}

Despite substantial TC progress in SSA in the last 15 years, more must still be done to avert a tobacco epidemic in the region. Stakeholders' efforts in and outside SSA need synergy to achieve the desired effects and cover more bases in SSA.

\section{What this paper adds}

Sub-Saharan Africa (SSA) has the lowest smoking prevalence globally, but aggressive marketing activities by the tobacco industry, youthful population growth and weak political will to effectively implement comprehensive policies contribute to the projected highest relative increase in tobacco use by 2025.

- Commitment from government, better use of the media (traditional/new), regional cooperation, funding to generate local data through research, as well as more cooperation among international funding agencies and civil society organisations are needed to boost tobacco control in SSA.

- Harmonisation of subregional tax policies must be implemented to remove tax limits and maximise taxation as a Tobacco Control tool in SSA.

\section{Twitter Peter Magati @magatipeter}

Contributors COE and OA-Y conceptualised the study. COE and PM drafted the initial manuscript. COE, PM, EW, LS, EO-D and OA-Y critically reviewed and revised the manuscript. All authors approved the final manuscript as submitted.

Funding This study was funded by South African Medical Research Council (NA). Competing interests None declared.

Patient consent for publication Not required.

Provenance and peer review Commissioned; externally peer reviewed.

\section{ORCID iDs}

Catherine O Egbe http://orcid.org/0000-0001-5698-6866

Olalekan A Ayo-Yusuf http://orcid.org/0000-0003-0689-7018 


\section{REFERENCES}

1 Blecher E, Ross H. Tobacco use in Africa: tobacco control through prevention. Atlanta, GA: American Cancer Society, 2013.

2 Reitsma MB, Kendrick PJ, Ababneh E, et al. Spatial, temporal, and demographic patterns in prevalence of smoking tobacco use and attributable disease burden in 204 countries and territories, 1990-2019: a systematic analysis from the global burden of disease study 2019. Lancet 2021;397:2337-60.

3 World Health Organization. WHO global report on trends in prevalence of tobacco smoking 2000-2025, 2019. Available: https://www.who.int/publications/i/item/ who-global-report-on-trends-in-prevalence-of-tobacco-use-2000-2025-third-edition [Accessed 4 April 2021].

4 Lutz W, KC S. Dimensions of global population projections: what do we know about future population trends and structures? Philos Trans R Soc Lond B Biol SCi 2010;365:2779-91.

5 The World Bank. Population growth (annual \%) - Sub-Saharan Africa. Available: https://data.worldbank.org/indicator/SP.POP.GROW?locations=ZG [Accessed 4 April 2021].

6 Vellios N, Ross H, Perucic A-M. Trends in cigarette demand and supply in Africa. PLoS One 2018;13:e0202467.

7 WHO Regional Office for Africa. State of health financing in the African region, 2013. Available: https://www.afro.who.int/sites/default/files/2017-06/state-of-healthfinancing-afro.pdf [Accessed 17 August 2021].

8 Assunta M. Global Tobacco Industry Interference Index 2019. Bangkok, Thailand.: Global Center for Good Governance in Tobacco Control (GGTC), 2020.

9 Peer N. Current strategies are inadequate to curb the rise of tobacco use in Africa. $S$ Afr Med J 2018;108:551-6.

10 The United Nations Treaty Collection. 4. a protocol to eliminate illicit trade in tobacco products, 2021. Available: https://treaties.un.org/Pages/ViewDetails.aspx?src= TREATY\&mtdsg_no=IX-4-a\&chapter=9\&clang=_en [Accessed 31 May 2021].

11 Campaign for Tobacco Free Kids. Tobacco control laws: policy factsheets, 2021. Available: https://www.tobaccocontrollaws.org/legislation/factsheet/ [Accessed 20 April 2021].

12 Sanni S, Hongoro C, Ndinda C, et al. Assessment of the multi-sectoral approach to tobacco control policies in South Africa and Togo. BMC Public Health 2018;18:1-12.

13 Egbe CO, Bialous SA, Glantz S. Framework convention on tobacco control implementation in Nigeria: lessons for low- and middle-income countries. Nicotine Tob Res 2019;21:1122-30.

14 STOP. South Africa, 2021. Available: https://exposetobacco.org/country/south-africa/ [Accessed 8 August 2021].

15 Egbe CO, Bialous SA, Glantz S. Role of stakeholders in Nigeria's tobacco control journey after the FCTC: lessons for tobacco control advocacy in low-income and middle-income countries. Tob Control 2019:28:386-93.

16 Thamm M. SARS Wars: Massive data leak alleges British American Tobacco SA's role in bribery and corruption, 2016. Available: https://www.dailymaverick.co.za/article/ 2016-08-16-sars-wars-massive-data-leak-alleges-british-american-tobacco-sas-rolein-bribery-and-corruption/ [Accessed 8 August 2021].

17 Bilton R. BBC Panorama: the secret bribes of big tobacco, 2015. Available: https:// www.bbc.com/news/business-34964603 [Accessed 8 August 2021].

18 Drope J, Lencucha R, Magati $\mathrm{P}$, et al. Tobacco control governance in sub-Saharan Africa: implementing article 5.2 (a) of the World Health Organization framework convention on tobacco control. Paper presented at: UNDP and WHO FCTC Convention Secretariat: New York, NY, 2016.

19 Krech R. Working on the social determinants of health is central to public health. J Public Health Pol 2012:33:279-84.

20 Piccagli GA. Facilitating negotiation and mediation. In: Mastering public health: essential skills for effective practice. 313, 2011.

21 Mcintyre D, Meheus F, Røttingen J-A. What level of domestic government health expenditure should we aspire to for universal health coverage? Health Econ Policy Law 2017:12:125-37.

22 WHO. The Abuja declaration: ten years on. Available: https://www.who.int/ healthsystems/publications/Abuja10.pdf [Accessed 9 August 2021].

23 WHO Tobacco Free Initiative (TFI). Overview of tobacco control in Africa, 2021. Available: https://apps.who.int/tobacco/control/capacity_building/africa/background/ overview/en/index.html [Accessed 10 April 2021].

24 Amico P, Aran C, Avila C. HIV spending as a share of total health expenditure: an analysis of regional variation in a multi-country study. PLoS One 2010;5:e12997.

25 Campaign for Tobacco Free Kids. Strategic investment of tobacco tax revenue, 2020. Available: https://www.tobaccofreekids.org/assets/global/pdfs/en/strategic_ investment_tobacco_tax_revenue.pdf [Accessed 19 August 2021].

26 Patterson AS, Gill E. Up in smoke? global tobacco control advocacy and local mobilization in Africa. Int Aff 2019:95:1111-30.

27 Africa Tobacco Control Alliance. Achievements of ATCA, 2021. Available: https://atcaafrica.org/en/about-us/achievements [Accessed 11 April 2021].

28 Drope J. Tobacco control in Africa: People, politics and policies. London, UK: Anthem Press, 2011

29 Center for Tobacco Control in Africa (CTCA). About us. Available: https://ctc-africa.org/ team/ [Accessed 27 October 2021]
30 Center for Tobacco Control in Africa (CTCA). A year in review: 2012 capacity building activities for Uganda, Kenya, Mauritania, South Africa and Angola, 2012. Available: https://ctc-africa.org/a-year-in-review-2012-capacity-building-activities-for-ugandakenya-mauritania-south-africa-and-angola/ [Accessed 27 October 2021].

31 Mamudu HM, Subedi P, Alamin AE, et al. The progress of tobacco control research in sub-Saharan Africa in the past 50 years: a systematic review of the design and methods of the studies. Int J Environ Res Public Health 2018;15:2732

32 Drope J, Schluger NW. The tobacco atlas. Atlanta, GA: American cancer society, 2018

33 Lencucha R, Reddy SK, Labonte R, et al. Global tobacco control and economic norms: an analysis of normative commitments in Kenya, Malawi and Zambia. Health Policy Plan 2018:33:420-8.

34 Rubert SC. A most promising weed: a history of tobacco farming and labor in colonial Zimbabwe, 1890-1945. Vol 69. Ohio University Press, 1998.

35 Blecher $E$. Increasing tobacco taxes significantly will increase revenues. A Tobacconomics policy brief, 2018Tobacconomics, Health Policy Center, Institute for Health Research and Policy, University of Illinois at Chicago. Available: www. tobacconomics.org

36 International Agency for Research on Cancer. IARC handbooks on cancer prevention, tobacco control, volume 14: effectiveness of Tax and price policies for tobacco control, 2011. Available: www.tobacconomics.org

37 World Health Organisation. WHO technical manual on tobacco tax policy and administration, 2021. Available: https://www.who.int/publications/i/item/ 9789240019188 [Accessed 30 May 2021].

38 World Health Organization. Who report on the global tobacco epidemic, 2015 raising taxes on tobacco. Geneva, CH World Health Organization; 2015. http://who. int/tobacco/global_report/2015/en/

39 World Health Organization. WHO report on the global tobacco epidemic 2021: addressing new and emerging products. Geneva World Health Organization; 2021. https://www.who.int/teams/health-promotion/tobacco-control/global-tobacco-report2021 [Accessed 26 October 2021].

40 Jackson R. Tobacco industry accused of 'intimidation and interference' in Kenya, 2015 theguardian.com. Available: https://www.theguardian.com/sustainable-business/ 2015/mar/02/tobacco-industry-accused-intimidation-interference-kenya

41 Directive CIDIR.1.12.17 on the harmonization of excise duties on tobacco products in ECOWAS member states. Available: http://ecotipa.ecowas.int/wp-content/uploads/ 2018/05/2-Excise-Duties-Harmnisation.pdf.

42 Santos-Paulino A, Thirlwall AP. The impact of trade liberalisation on exports, imports and the balance of payments of developing countries. Econ J 2004;114:F50-72.

43 Tesche J, Van Walbeek C. Measuring the effects of the new ECOWAS and WAEMU tobacco excise tax directives. Tob Control 2021;30:668-74.

44 World Health Organization. WHO technical manual on tobacco Tax policy and administration, 2021. Available: https://www.who.int/publications/i/item/ 9789240019188

45 World Health Organization. Status of tobacco production and trade in Africa, 2021. Available: https://cdn.who.int/media/docs/default-source/tobacco-hq/ globalinfographic-web-feb11.pdf?sfvrsn=827aee77_5 [Accessed 30 August 2021].

46 Lencucha R, Drope J. How does tobacco growing impact advancement in demand reduction measures? Tob Prev Cessat 2021;7:1-4.

47 Court allows Malawian child farmer claims against British American tobacco and imperial to proceed, 2021. Available: https://www.leighday.co.uk/latest-updates/ news/2021-news/court-allows-malawian-child-farmer-claims-against-britishamerican-tobacco-and-imperial-to-proceed/ [Accessed 17 August 2021].

48 Magati P, Lencucha R, Li Q, et al. Costs, contracts and the narrative of prosperity: an economic analysis of smallholder tobacco farming livelihoods in Kenya. Tob Control 2019;28:268-73.

49 Makoka D, Drope J, Appau A, et al. Costs, revenues and profits: an economic analysis of smallholder tobacco farmer livelihoods in Malawi. Tob Control 2017;26:634-40.

50 McDaniel PA, Cadman B, Malone RE. African media coverage of tobacco industry corporate social responsibility initiatives. Glob Public Health 2018;13:129-43.

51 Modjadji M, Cullinan K. Professionals co-opted to back tobacco giants, 2018. Available: https://www.dailymaverick.co.za/article/2018-08-19-professionals-coopted-to-back-tobacco-giants/ [Accessed 17 August 2021].

52 Crosbie E, Defrank V, Egbe CO, et al. Tobacco supply and demand strategies used in African countries. Bull World Health Organ 2021;99:539.

53 Snyckers T. Dirty tobacco: spies, lies and mega-profits. Cape Town: Tafelberg Publishers, 2020

54 Lift the ban SA. Available: https://www.facebook.com/pg/LiftTheBanSA/posts/ [Accessed 19 August 2021].

55 Freeman B. New media and tobacco control. Tob Control 2012;21:139.

56 Liang $Y$, Zheng $X$, Zeng DD, et al. Exploring how the tobacco industry presents and promotes itself in social media. J Med Internet Res 2015;17:e24.

57 Ayman T, Ameen T. The role of social media in influencing smoking among Youths. J Econ Bus Stud 2020;3:149.

58 Network of African Science Academies. Preventing a tobacco epidemic in Africa: a call for effective action to support health, social, and economic development: report of the Committee on the Negative Effects of Tobacco on Africa's Health, Economy, and Development., 2014. Available: https://www.assaf.org.za/images/AfricaTobaccoCon trolReportFinal1.pdf [Accessed 19 August 2021]. 
59 Protext our next campaign. Available: http://www. pressa.africa/protectournext [Accessed 19 August 2021].

60 CEHURD. Tobacco free Uganda. Available: https://www.cehurd.org/tobacco-freeuganda/ [Accessed 19 August 2021].

61 Lee S, Ling PM, Glantz SA. The vector of the tobacco epidemic: tobacco industry practices in low and middle-income countries. Cancer Causes Control 2012;23 Suppl 1:117-29.

62 Kamadi G. Stand-off between Kenyan government and Tobacco multinational over 'nicotine pouches', 2021. Available: https://healthpolicy-watch.news/stand-offbetween-kenyan-government-and-tobacco-multinational-over-nicotine-pouches/ [Accessed 9 August 2021].
63 Tobacco tactics. nicotine pouches, 2021. Available: https://tobaccotactics.org/wiki/ nicotine-pouches/ [Accessed 9 August 2021].

64 Ayo-Yusuf OA, Burns DM. The complexity of 'harm reduction' with smokeless tobacco as an approach to tobacco control in low-income and middle-income countries. Tob Control 2012;21:245-51.

65 Leischow SJ, Ayo-Yusuf O, Backinger CL. Converging research needs across framework convention on tobacco control articles: making research relevant to global tobacco control practice and policy. Nicotine Tob Res 2013;15:761-6.

66 The United Nations Treaty Collection. WHO framework convention on tobacco control, 2021. Available: https://treaties.un.org/pages/ViewDetails.aspx?src=TREATY\&mtdsg_ no=|X-4\&chapter=9\&clang=_en\#EndDec [Accessed 10 April 2021]. 